\title{
Analysis of Superior Commodities in Agricultural Sector in Some Districts of North Sumatera Province
}

\author{
Nela Permata Sari Lubis ${ }^{1}$, Eko Wahyu Nugrahadi ${ }^{\mathbf{2}}$, M. Yusuf ${ }^{\mathbf{2}}$ \\ ${ }^{1}$ Master Student in State University of Medan (Unimed), Medan, Indonesia \\ ${ }^{2}$ Lecturer in State University of Medan (Unimed), Medan, Indonesia \\ nelapermatasari1410@gmail.com
}

\section{Abstract:}

Realization of regional economic development requires policies that are endogenous development. Each region has a base sector as the main driving force in economic growth. The base sector must have resilience between other sectors and have a high contribution to the formation of total regional economic output. North Sumatra is one of the provinces in Indonesia which has a tendency towards economic structure in the agricultural sector. Viewed from the field of business, the agricultural sector provides the highest contribution in the formation of GRDP. North Sumatra has 25 districts with a variety of geographical conditions having varied natural resources that need to be intensified and explored. The purpose of this study is to analyze the leading commodities of the agricultural sector and find out how much the impact of the leading sector on the growth of North Sumatra GRDP in the period 2014 2018. The method of analysis in this study uses the Location Quotient (LQ) analysis, Revelead Comparative Advantage (RCA) analysis, and Panel Data Regression Analysis. The estimation results show that the agriculture, livestock, hunting and services sub-sectors, the forestry sub-sector and the fisheries sub-sector have a positive and significant effect on the economic growth of the province of North Sumatra. The economic growth variables can be explained by 89 percent by the variables of the agriculture, livestock, hunting and service subsectors, the forestry subsector and the fisheries subsector while the rest are explained by variables not included in this study.

Keywords

Main Commodity, Economic Growth, Location Quotient, Dousalod romnaratison

\section{Introduction}

One indicator used to measure the economic condition of a region is Gross Domestic Product (GDP) for the national level and Gross Regional Domestic Product (GRDP) for provincial and district / city levels. Based on the size of the role of each sector in the formation of a region's GRDP, it can be seen the direction of the economic structure of the region. The economic development of a region will cause changes in the role of each sector resulting in changes in the economic structure of the area (Irwansyah, 2013).

Indonesia is an agricultural country that has great potential in the agricultural sector. Based on data from the Ministry of Agriculture, the area of Indonesia's rice fields reaches 7.6 million ha. North Sumatra is one of the provinces that have potential in the agricultural sector. The area of agricultural land in North Sumatra is around 34\% of the total land area in Indonesia. North Sumatra is a province consisting of 33 regencies / cities. Each district and city has a diversity of geographical conditions that are different from the others.

If seen from the North Sumatra's GRDP real growth rate, in 2018 the agriculture, forestry and fisheries sectors experienced a decline in growth rate of $0.44 \%$, meaning that the business structure of some of the people of North Sumatra shifted from the agriculture, 
forestry and fisheries to the business fields other economics. As for other business fields that experienced an increase in growth rates such as the mining and quarrying sector by $0.65 \%$, the manufacturing industry sector increasing by $1.35 \%$, the wholesale and retail trade sector; car and motorcycle operations increased by $0.24 \%$, the accommodation and food and beverage providers sector increased by $0.21 \%$ and the financial services and insurance sector experienced an increase in growth rate of $1.24 \%$. We can see more in the table below.

Graph 1. Development of the GRDP GDP Real Growth Rate

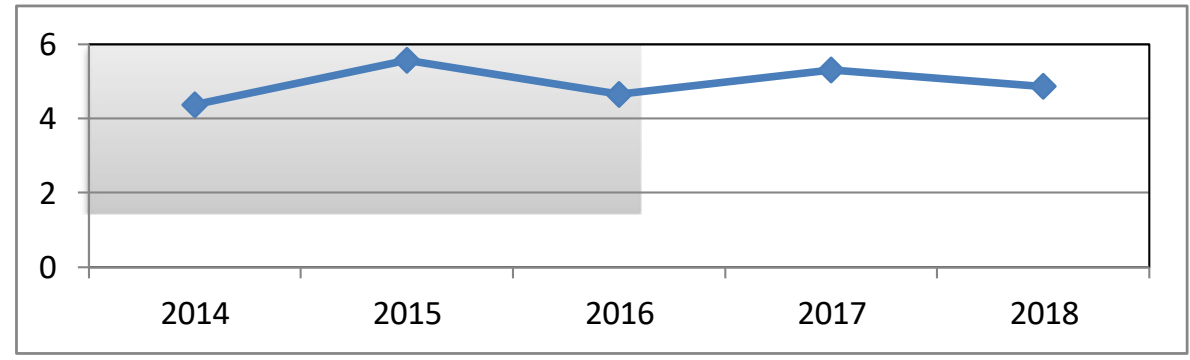

Sources: SUDA 2015 and SUDA 2018, BPS North Sumatra (Processed)

Agricultural development is not just a process or activity in increasing agricultural production, but a process that results in social change in terms of values, norms, behavior, people's lives and so on. In order to achieve good economic growth and improve the welfare of the community, especially in farmers (Pranoto and Moelyo 2018).

The role of the agricultural sector given to the economic development of North Sumatra is very large, so the agricultural sector must continue to be developed by the government, but on the other hand the fact that the agricultural sector has decreased is very unfortunate. This was conveyed by Arifin (2001) who explained that the main cause of the decline in the role of the agricultural sector was the growth of agricultural production which was still too based on land availability, even though there were a number of economic activities accompanied by conversion of agricultural land to other uses. Not only that, the current condition of the agricultural sector is experiencing symptoms of acceptance of output which continues to decrease because the allocation and combination of agricultural production factors used are still said to be unable to offset the decline that is happening.

The decline in the role of the agricultural sector can be controlled by policies focused on developing the agricultural sector in North Sumatra based on the concept of efficiency. Interpreting the efficiency of agricultural resource development that can be pursued by developing commodities that have a comparative advantage in biophysical aspects (location, land) and socioeconomic aspects (technological mastery, human resource capacity of infrastructure exemplified such as markets and habits of farmers in each region) (Syafa 'at, 2000). The development of this superior sector is not only the duty of the government alone, but also requires an active role and community initiative in processing local resources, both from human resources and natural resources available to create a product that has competitiveness, so that it is expected to improve the economy region and competitiveness with other regions around it (Indramayu and Mustikaningrum, 2018).

One of the opportunities in overcoming the problem of economic development is the need to sharpen development orientation based on regional potential. Each region is encouraged not only to be more able to take roles and initiatives in development planning, but also to be more observant in exploring and exploiting resources aimed at the welfare of the local people (Prawoto, 2010). 
Therefore, economic growth that is supported by the presence of leading commodities can be used as potential for the development of the local community. (Oktavia and Hanani,

2016). This was made clear by Taufik in (Yulianita, 2009) that leading commodities made two contributions in the form of direct effects that could make an increase in the income of regional production factors and regional income as well as for local industrial production which would generate demand that helped local industries to continue to grow .

Based on the description above, it is important to know the superior sector for planning with better and directed prospects for the development of the sector itself and be able to encourage other sectors to develop. As a developing country with favorable geographical and land conditions, it is not surprising that the agricultural sector plays an important role in economic development to achieve better economic development. This statement is supported by research conducted (Enu, 2014) with the research title "Analysis Of Agricultural Sector Of Ghana And Its Economic Impact On Economic Growth" shows that the agricultural sector is the key to economic growth and development processes in the country of Ghana and has a broad effect on variables other economies such as employment and being a supplier of raw materials in the growth and development of the industrial world.

\section{Literature Review}

\subsection{The Role of the Agricultural Sector in Regional Economic Development}

Traditionally, the role of agriculture in economic development is only seen as passive and as a mere supporting element (Todaro and Smith, 2006). Based on historical theories adopted from western countries, economic development leads to structural transformation of development into modern industries and more complex services to the economy. The main function of agriculture is considered as a cheap source of labor and staples while the industrial sector is chosen as the leading sector that plays a major role in the global economic development strategy.

According to (Haris, 2018) the agricultural sector is one of the important sectors in economic development both in national and regional scope. The output of the agricultural sector contributes to various economic sectors, including food providers, feed ingredients, small, medium to large industrial raw materials, contributors to Gross Domestic Product (GDP), employment, and the main source of rural household income. The contribution of the agricultural sector to the national GDP in 2017 reached $18 \%$ with an average growth of around $9.71 \%$ in 2012 to 2016. (BPS, 2017).

The efficiency of agricultural resource development that can be achieved by developing commodities that have a comparative advantage in biophysical aspects (location, land) and socioeconomic aspects (technological mastery, infrastructure human resource capabilities are exemplified such as markets and farmers' habits in each region) (Oktavia and Hanani , 2016).

\subsection{Leading Sector Development as a Regional Development Strategy}

The level of regional development differs depending on the potential in each region. This has an impact on the occurrence of sectoral differences in the formation of GRDP (Gross Regional Domestic Product). The greater the contribution of the economic sector that has added value to the formation of GRDP in a region, the higher the rate of growth of regional income.

Leading commodities are commodities that have a comparative advantage in terms of supply and demand. From the supply side of superior commodities characterized by superiority in its growth in the biophysical, technological, and socio-economic conditions of farmers in a region. Meanwhile, from the demand side, leading commodities are characterized by strong demand in both domestic and international markets. (Intercession in Hendayana (2003: 1). Leading sectors also provide added value and large production, have a 
large multiplier effect on other economies, and have high demand both local and export markets (Wulandari, 2010).

The understanding of leading sectors is basically associated with a form of comparison, be it international, regional or national scale comparisons. Internationally, a sector is said to be superior if the sector is able to compete with the same sector with other countries. Whereas in the national scope, a sector can be categorized as a superior sector if a sector in a certain region is able to compete with the same sector produced by other regions, both in the national or domestic market. (Bahri, 2018).

GRDP is very important information to determine output in the economic sector and see growth in a particular region (province / district / city). With the help of GRDP data, the leading sector can be determined in an area / region. Leading sector is a sector / sub-sector group that is able to encourage economic activities and create prosperity in an area mainly through production, export and job creation, so identification of leading sectors is very important especially in the context of determining priorities and planning for economic development in the region. (Bahri, 2018).

The determination of leading sectors is important as a basis for regional development planning in accordance with the current era of regional autonomy, where regions have the opportunity and authority to make policies that are in line with regional potential in order to accelerate regional economic development to increase community prosperity (Bahri, 2018)

According to Yusuf (2013: 19) there are four conditions for a particular sector to become a priority sector:

1. The sector must produce products that have a large enough demand, so that the growth rate develops quickly due to the effect of the demand.

2. Because there is a change in technology that is adopted creatively, the new production function shifts with wider capacity development.

3. There must be an increase in investment returns from the production results of the priority sectors, both private and government.

4. The sector must develop, so that it can give effect to other sectors.

By knowing the leading sectors of an area is able to provide an indication for the economy nationally and regionally. Leading sectors have greater potential and are certain to grow when compared to other economic sectors. This is due to supporting factors, namely capital accumulation, employment growth, technology advancements and investment opportunities. The creation of investment opportunities can also be done by empowering the potential of leading sectors owned by the region concerned.

\subsection{Revealed Comparative Advantage (RCA) Method}

One method used to determine a country's comparative advantage is the Revealed Comparative Advantage (RCA) method. The RCA method is a measurement method that was first introduced by Bella Balassa. David Ricardo's comparative advantage theory says two countries will trade if the trade provides profits for both countries. The value of profits can be seen from the country's domestic power. If a country can buy a commodity from another country at a cheaper price than self-producing and selling profitable commodities, there will be trade.

Revealed Comparative Advantage (RCA) is a number that shows the comparative advantage level of an export commodity from a certain country compared to the same commodity from all other countries in the world (Yusuf, 2012: 67).

The formula to calculate RCA is:

Where

$\mathrm{XiN}=$ Value of commodity exports i from country $\mathrm{N}$

$\mathrm{XN} \quad=$ export value of all commodities from country $\mathrm{N}$ 
$\mathrm{XiW}=$ Value of commodity export I from all countries (world)

$\mathrm{XN} \quad=$ The leading value of all commodities from all countries (world)

- An RCA value of $<1$ means that the export commodity has no comparative advantage.

-The RCA value $=1$ indicates that export commodities have the same comparative advantage as the average of all countries in the world.

An RCA number $>1$ means that export commodities have a comparative advantage that is higher than the comparative advantages of other countries.

\section{Research Methods}

The scope of this research focuses on the discussion of leading commodities forming agriculture sector with 4 sub-sectors namely food crops, plantations, livestock and fisheries sub-sectors which can be used as priority development planning materials in 25 districts in North Sumatra province. The type of data to be analyzed in this study is quantitative, namely secondary data obtained from the Central Statistics Agency (BPS) of North Sumatra Province. The data used to be analyzed include the GRDP of PerKapita Regency and Province, the value of agricultural sector commodity production, LQ value and RCA value. Data analysis method used in this research is quantitative with panel data analysis model. To choose which model is the most appropriate for panel data processing, there are several tests that can be done with the chow test, the human test, the lagrange multiplier test. T test is used to find out how much the independent variable significantly influences the dependent variable partially (Ghozali, 2013). The F test is used to find out how much the independent variable significantly influences the dependent variable together (Ghozali, 2013). According to Gujarati and Porter (2012: 97) the magnitude of R2 is known as the coefficient of determination which is the most commonly used measure to measure the goodness offit of a regression line.

\section{Discussion}

\subsection{Research Results}

\section{a. Results of LQ Method Analysis}

LQ analysis is a comparison of the magnitude of the role of the agricultural sector between districts against the magnitude of the role of the agricultural sector in the province of North Sumatra. LQ value> 1, meaning that the role of commodity $i$ in regency $r$ is greater than the role of commodity $i$ at the level of the province of North Sumatra.

The results of the processing of LQ analysis of inter-regency agriculture sector in North Sumatra province will be elaborated as follows:

1. Agriculture, Animal Husbandry, Hunting and Agricultural Services Subsectors

Agriculture, animal husbandry, hunting and agriculture services are the leading sectors or bases in several districts in North Sumatra, namely: Nias district, Mandailing Natal, South Tapanuli, Central Tapanuli, North Tapanuli, Simalungung, Dairi, Karo, Deli Serdang, South Nias Langkat, Humbang Hasundutan, Pakpak Bharat, Serdang Bedagai and Coal. This explains that the agriculture, livestock, hunting and services sub-sectors affect North Sumatra's GRDP. The increase in the value of LQ is inseparable because North Sumatra, especially some base districts, have vast and fertile natural resources, the community is also able to utilize the available Natural Resources. More clearly can be seen in the table below. 
Table 1. LQ Agriculture, Animal Husbandry, Hunting and Inter-District Subsectors in North Sumatra Province

\begin{tabular}{clccccc}
\hline \multirow{2}{*}{ No District } & & \multicolumn{4}{c}{$\begin{array}{c}\text { Agriculture, Animal Husbandry, } \\
\text { Hunting Subsector and services }\end{array}$} \\
\cline { 3 - 7 } & & $\mathbf{2 0 1 4}$ & $\mathbf{2 0 1 5}$ & $\mathbf{2 0 1 6}$ & $\mathbf{2 0 1 7}$ & $\mathbf{2 0 1 8}$ \\
\hline 1 & Nias & 1,26 & 1,50 & 1,60 & 1,09 & 1,74 \\
2 & Mandailing Natal & 2,09 & 2,04 & 2,08 & 2,06 & 2,02 \\
3 & Tapanuli Selatan & 1,25 & 1,75 & 1,70 & 1,30 & 1,34 \\
4 & Tapanuli Tengah & 1,04 & 1,02 & 1,05 & 1,01 & 1,08 \\
5 & Tapanuli Utara & 1,77 & 1,45 & 1,55 & 1,98 & 2,09 \\
6 & Toba Samosir & 0,75 & 0,63 & 0,48 & 0,76 & 0,64 \\
7 & Labuhanbatu & 0,42 & 0,36 & 0,40 & 0,66 & 0,64 \\
8 & Asahan & 0,96 & 0,92 & 0,91 & 0,95 & 0,94 \\
9 & Simalungun & 1,79 & 1,98 & 1,96 & 1,88 & 1,94 \\
10 & Dairi & 1,61 & 2,41 & 3,43 & 2,60 & 1,86 \\
11 & Karo & 1,30 & 1,48 & 1,31 & 1,86 & 1,48 \\
12 & Deli Serdang & 2,64 & 2,33 & 2,09 & 2,88 & 2,21 \\
13 & Langkat & 1,81 & 1,87 & 1,90 & 1,32 & 1,05 \\
14 & Nias Selatan & 1,21 & 1,31 & 1,29 & 1,68 & 0,53 \\
15 & Humbang Hasundutan & 1,23 & 1,02 & 1,09 & 1,70 & 2,07 \\
16 & Pakpak Bharat & 1,19 & 1,12 & 1,16 & 1,39 & 1,22 \\
17 & Samosir & 0,78 & 0,69 & 0,52 & 0,87 & 0,72 \\
18 & Serdang Bedagai & 2,16 & 2,06 & 2,85 & 2,13 & 2,19 \\
19 & Batubara & 1,90 & 1,72 & 1,12 & 1,05 & 1,87 \\
20 & Padang Lawas Utara & 0,54 & 0,61 & 0,86 & 1,08 & 1,32 \\
21 & Padang Lawas & 0,32 & 0,31 & 0,27 & 0,00 & 1,27 \\
22 & Labuhanbatu Selatan & 0,03 & 0,02 & 0,03 & 0,02 & 0,04 \\
23 & Labuhan batu Utara & 0,28 & 0,27 & 0,46 & 0,57 & 0,64 \\
& & 0,16 & 0,19 & 0,35 & 0,00 & 0,40 \\
24 & Nias Utara & & & & & \\
25 & Nias Barat & 0,22 & 0,29 & 0,42 & 0,57 & 0,65 \\
\hline
\end{tabular}

Source: Processed Data

Some districts that have this sector basis tend to be able to meet their own regional needs and make it possible to export out of the area in the subsector. This is related to the topography of the regency which has varied landforms so that it can produce diverse agricultural, livestock, hunting and service commodities.

\section{Forestry Subsector}

In North Sumatra there are about 12 districts where the forestry sub-sector as one of the base or superior sectors consists of Mandailing Natal, South Tapanuli, Central Tapanuli, North Tapanuli, Toba Samosir, Dairi, Humbang Hasundutan, Pakpak Bharat, Samosir, Paluta, and North Nias . This shows that some of these districts are able to carry out trading / export activities of forestry commodities outside the region or other districts which are nonbase sectors. More clearly can be seen in the table below. 
Table 2. LQ Value of Inter-Regency Fisheries Subsector in North Sumatra Province

\begin{tabular}{|c|c|c|c|c|c|c|}
\hline \multirow{2}{*}{ No } & \multirow{2}{*}{ District } & \multicolumn{5}{|c|}{ Fisheries Subsector } \\
\hline & & 2014 & 2015 & 2016 & 2017 & 2018 \\
\hline 1 & Nias & 1,16 & 1,07 & 1,08 & 1,06 & 1,08 \\
\hline 2 & Mandailing Natal & 1,72 & 1,47 & 1,52 & 1,35 & 1,39 \\
\hline 3 & Tapanuli Selatan & 0,23 & 0,01 & 0,02 & 0,03 & 0,05 \\
\hline 4 & Tapanuli Tengah & 2,77 & 2,79 & 2,34 & 2,46 & 2,44 \\
\hline 5 & Tapanuli Utara & 0,17 & 0,15 & 0,06 & 0,04 & 0,07 \\
\hline 6 & Toba Samosir & 1,78 & 1,01 & 1,06 & 1,04 & 1,05 \\
\hline 7 & Labuhanbatu & 1,44 & 1,01 & 1,13 & 1,06 & 1,08 \\
\hline 8 & Asahan & 1,26 & 1,11 & 1,49 & 1,51 & 1,29 \\
\hline 9 & Simalungun & 2,48 & 2,39 & 2,19 & 2,18 & 2,66 \\
\hline 10 & Dairi & 0,06 & 0,06 & 0,02 & 0,01 & 0,07 \\
\hline 11 & Karo & 0,17 & 0,04 & 0,01 & 0,03 & 0,04 \\
\hline 12 & Deli Serdang & 1,96 & 1,82 & 1,31 & 1,24 & 1,27 \\
\hline 13 & Langkat & 0,96 & 0,77 & 0,27 & 0,37 & 0,38 \\
\hline 14 & Nias Selatan & 1,86 & 1,22 & 1,46 & 1,33 & 1,36 \\
\hline 15 & Humbang Hasundutan & 0,27 & 0,23 & 0,06 & 0,05 & 0,06 \\
\hline 16 & Pakpak Bharat & 0,03 & 0,66 & 0,56 & 0,64 & 0,60 \\
\hline 17 & Samosir & 2,14 & 2,04 & 2,05 & 2,44 & 2,39 \\
\hline 18 & Serdang Bedagai & 1,17 & 1,99 & 1,77 & 1,59 & 1,39 \\
\hline 19 & Batubara & 1,09 & 1,73 & 1,06 & 1,46 & 1,53 \\
\hline 20 & Padang Lawas Utara & 0,17 & 0,14 & 0,06 & 0,04 & 0,06 \\
\hline 21 & Padang Lawas & 0,03 & 0,05 & 0,04 & 0,02 & 0,07 \\
\hline 22 & Labuhanbatu Selatan & 0,19 & 0,11 & 0,12 & 0,12 & 0,22 \\
\hline 23 & Labuhanbatu Utara & 0,45 & 0,41 & 0,42 & 0,40 & 0,44 \\
\hline 24 & Nias Utara & 1,67 & 1,11 & 1,08 & 1,84 & 1,94 \\
\hline 25 & Nias Barat & 0,06 & 0,07 & 0,03 & 0,84 & 0,02 \\
\hline
\end{tabular}

Source: Data process

\section{b. Results of RCA Method Analysis}

The RCA (Revealed Comparative Advantage) method is an index that measures the export performance of a commodity from a country by evaluating the role of exports of a commodity in the country's total exports, compared to the share of these commodities in world trade (Kuncoro, 2008).

Table 3. RCA Calculation Results for the Agriculture, Livestock, Hunting, and Inter-District Subsector Services in North Sumatra Province

\begin{tabular}{|c|c|c|c|c|c|c|}
\hline \multirow[t]{2}{*}{ No } & \multirow[t]{2}{*}{ District } & \multicolumn{5}{|c|}{$\begin{array}{l}\text { Agriculture, Animal Husbandry, } \\
\text { Hunting and Services Subsector }\end{array}$} \\
\hline & & 2014 & 2015 & 2016 & 2017 & 2018 \\
\hline 1 & Nias & 0,88 & 0,89 & 0,88 & 0,89 & 0,87 \\
\hline 2 & Mandailing Natal & 0,89 & 0,84 & 0,88 & 0,87 & 0,89 \\
\hline 3 & Tapanuli Selatan & 1,34 & 1,34 & 1,36 & 1,35 & 1,36 \\
\hline 4 & Tapanuli Tengah & 1,08 & 1,07 & 1,08 & 1,08 & 1,07 \\
\hline 5 & Tapanuli Utara & 0,77 & 0,78 & 0,78 & 0,76 & 0,77 \\
\hline 6 & Simalungun & 1,79 & 1,78 & 1,76 & 1,78 & 1,74 \\
\hline
\end{tabular}




\begin{tabular}{|c|c|c|c|c|c|c|}
\hline \multirow[t]{2}{*}{ No } & \multirow[t]{2}{*}{ District } & \multicolumn{5}{|c|}{$\begin{array}{l}\text { Agriculture, Animal Husbandry, } \\
\text { Hunting and Services Subsector }\end{array}$} \\
\hline & & 2014 & 2015 & 2016 & 2017 & 2018 \\
\hline 7 & Dairi & 1,73 & 1,72 & 1,73 & 1,71 & 1,72 \\
\hline 8 & Karo & 1,30 & 1,38 & 1,31 & 1,36 & 1,38 \\
\hline 9 & Deli Serdang & 1,64 & 1,65 & 1,64 & 1,67 & 1,66 \\
\hline 10 & Langkat & 0,91 & 0,97 & 0,90 & 0,92 & 0,92 \\
\hline 11 & Nias Selatan & 0,82 & 0,83 & 0,89 & 0,88 & 0,83 \\
\hline 12 & Humbang Hasundutan & 1,23 & 1,22 & 1,29 & 1,28 & 1,29 \\
\hline 13 & Pakpak Bharat & 0,19 & 0,12 & 0,16 & 0,17 & 0,18 \\
\hline 14 & Serdang Bedagai & 1,19 & 1,18 & 1,18 & 1,19 & 1,19 \\
\hline 15 & Batubara & 0,89 & 0,88 & 0,89 & 0,85 & 0,86 \\
\hline
\end{tabular}

Source: Processed Data

The table above shows the results that there are several where the agriculture, animal husbandry, hunting and service subsectors are basic/ competitive commodities and are competitive, including the districts of South Tapanuli, Central Tapanuli, Simalungun, Dairi, Karo, Deli Serdang, Langkat and South Nias.

Table 4. Inter-District Forestry Subsector RCA Calculation Results in North Sumatra Province

\begin{tabular}{llccccc}
\hline \multirow{2}{*}{ No } & \multicolumn{1}{c}{ District } & \multicolumn{5}{c}{ Forestry Subsector } \\
\cline { 3 - 7 } & & $\mathbf{2 0 1 4}$ & $\mathbf{2 0 1 5}$ & $\mathbf{2 0 1 6}$ & $\mathbf{2 0 1 7}$ & $\mathbf{2 0 1 8}$ \\
\hline 1 & Mandailing Natal & 1,32 & 1,33 & 1,34 & 1,33 & 1,33 \\
2 & Tapanuli Selatan & 1,68 & 1,64 & 1,68 & 1,69 & 1,67 \\
3 & Tapanuli Tengah & 1,53 & 1,54 & 1,52 & 1,55 & 1,55 \\
4 & Tapanuli Utara & 0,89 & 0,88 & 0,88 & 0,89 & 0,89 \\
5 & Toba Samosir & 0,17 & 0,18 & 0,17 & 0,19 & 0,18 \\
6 & Dairi & 0,78 & 0,79 & 0,77 & 0,78 & 0,78 \\
7 & Humbang Hasundutan & 1,28 & 1,28 & 1,27 & 1,28 & 1,29 \\
8 & Pakpak Bharat & 1,53 & 1,55 & 1,52 & 1,54 & 1,51 \\
9 & Samosir & 1,86 & 1,87 & 1,86 & 1,84 & 1,84 \\
10 & Padang Lawas Utara & 0,87 & 0,88 & 0,87 & 0,86 & 0,87 \\
11 & Padang Lawas & 1,16 & 1,18 & 1,19 & 1,19 & 1,19 \\
12 & Nias Utara & 0,18 & 0,17 & 0,19 & 0,18 & 0,17 \\
\hline
\end{tabular}

Source: Processed Data

The table above shows the results that there are several where the forestry sub-sector as a commodity / superior and competitive include Mandailing Natal, South Tapanuli, Central Tapanuli, Humbang Hasundutan, Pakpak Bharat, Samosir, North Padang Lawas, Padang Lawas, and North Nias.

Table 5. Results of Calculation of Inter-Regency Fisheries Subsector RCA in North Sumatra Province

\begin{tabular}{llrcccc}
\hline \multirow{2}{*}{ No } & \multirow{2}{*}{ District } & \multicolumn{5}{c}{ Fisheries Subsector } \\
\cline { 3 - 7 } & & $\mathbf{2 0 1 4}$ & $\mathbf{2 0 1 5}$ & $\mathbf{2 0 1 6}$ & $\mathbf{2 0 1 7}$ & $\mathbf{2 0 1 8}$ \\
\hline 1 & Nias & 0,66 & 0,67 & 0,68 & 0,66 & 0,68 \\
2 & Mandailing Natal & 1,39 & 1,38 & 1,38 & 1,37 & 1,38 \\
3 & Tapanuli Tengah & 1,77 & 1,79 & 1,78 & 1,77 & 1,78 \\
\hline
\end{tabular}




\begin{tabular}{llccccc}
\hline \multirow{2}{*}{ No } & \multicolumn{1}{c}{ District } & \multicolumn{5}{c}{ Fisheries Subsector } \\
\cline { 3 - 7 } & & $\mathbf{2 0 1 4}$ & $\mathbf{2 0 1 5}$ & $\mathbf{2 0 1 6}$ & $\mathbf{2 0 1 7}$ & $\mathbf{2 0 1 8}$ \\
\hline 4 & Toba Samosir & 1,68 & 1,67 & 1,66 & 1,67 & 1,68 \\
5 & Labuhanbatu & 0,88 & 0,89 & 0,89 & 0,87 & 0,88 \\
6 & Asahan & 1,26 & 1,25 & 1,26 & 1,27 & 1,28 \\
7 & Simalungun & 1,88 & 1,89 & 1,89 & 1,88 & 1,86 \\
8 & Deli Serdang & 1,82 & 1,82 & 1,83 & 1,84 & 1,85 \\
9 & Nias Selatan & 0,77 & 0,78 & 0,75 & 0,76 & 0,77 \\
10 & Samosir & 1,14 & 1,15 & 1,16 & 1,17 & 1,18 \\
11 & Serdang Bedagai & 1,18 & 1,19 & 1,17 & 1,18 & 1,19 \\
12 & Batubara & 0,79 & 0,78 & 0,78 & 0,77 & 0,79 \\
13 & Nias Utara & 1,17 & 1,18 & 1,18 & 1,18 & 1,19 \\
\hline Source: & Processed Data & & & & &
\end{tabular}

The table above shows the results that for some where the fisheries sub-sector as a commodity / superior and competitive include Nias district, Mandailing Natal, Central Tapanuli, Toba Samosir, Labuhan Batu, Asahan, Simalungun, Deli Serdang, South Nias, Samosir, Serdang Bedagai, Coal, and North Nias.

\subsection{Results of Data Analysis Models}

\section{a. Classical Assumption Test Results}

\section{Normality Test}

Normality test is a test to see whether the residual value is normally distributed or not. A good regression model is to have a normally distributed residual value. Normality test is done by comparing the probability value of JB (Jarque-Bera) count with an Alpha level of $0.05(5 \%)$. From the results of the normality test it is known that the value of prob. JB of $0.203>=0.05$, thus it is said that the model used has residuals that are normally distributed.

\section{Multicollinearity Test}

Multicollinearity test aims to test whether there is a high correlation between independent variables in an regression model (Widarjono, 2013). According to Gujarati, 2018 that the limit of the correlation between independent variables is not to be more than an absolute sign of 0.8. Multicollinearity test results showed all correlation coefficients were below 0.8. Based on these results we can conclude that there is no multicollinearity because the correlation coefficient between independent variables under the conditions of multicollinearity is equal to 0.8 .

\section{Heterokedasticity Test}

The decision whether or not heterokedasticity occurs in the linear regression model by looking at prob. F-Statistics. If the value is greater than alpha $0.05 \%(5 \%)$, heterokedasticity does not occur and vice versa. Heterokedastisitas test results indicate there is a probability value of each variable> 0.05 . Then there is no heterokedasticity in the model.

\section{Autocorrelation Test}

An autocorrelation test was performed to see the value of the Durbn Watson Stat. In the Durbin Watson table the significance level $=0.05$, with the total value of $n=25$ and the number of independent variables $\mathrm{k}=1$ there is a value of $\mathrm{dL}=1.6592$ and $\mathrm{dU}=1.7574$. The Durbin Watson calculation results show that $\mathrm{HO}$ is accepted, meaning that there is no autocorrelation based on the Durbin-Watson value obtained with a 5\% significance value of 1.954632 . 


\section{b. Results of Data Analysis Techniques}

In panel data processing it is necessary to analyze the selection of the most appropriate model, which is between Common Effect, Fixed Effect and Random Effect models. There are several ways of testing that can be done to select the three estimation models, namely:

\section{Chow Test}

Chow Test is used to determine the selection of the right model used between the Common Effect or Fixed Effect, with the hypothesis H0 means the Common Effect Estimation and Hi means the Fixed Eject Estimation. The calculation results obtained that the value of Prob. Cross Section F of $0.0000<0.05$ so it can be concluded that H0 is rejected and $\mathrm{H} 1$ is accepted, meaning that Fixed Effect is more appropriate to be used in the estimation model.

\section{Hausman Test}

Hausman test is used to determine the model that will be used between the Fixed Effect Model or Random Effect Model with the hypothesis test H0 means Random Effect Model Estimation and H1 means Fixed Effect Model Estimation. The calculation results obtained a probability value (Prob.) Cross-Section random of 0.0035 whose value $<0.05$ so that it can be concluded that the chosen model is the Fixed Effect Model (H0 ditolak is rejected and H1 is accepted).

\subsection{Interpretation of Analysis Results}

Based on the results of the Chow and Hausman test it was concluded that the right model was used to estimate the data of this study with the Fixed Effect Model. This model assumes that differences between individuals (Cross Section) can be accommodated from differences in different intercepts indicating that the area is different from other regions. Based on the results of the Fixed Effect Model test can be written models of equation functions in this study, namely:

$$
\begin{aligned}
& \text { Yit }=6,055155+1,478361 \text { SUB } 1 \text { it }+0.043550 \text { SUB2it }+0.082362 \text { SUB } 2 i t+\varepsilon i t \\
& \text { Information } \quad: \\
& \text { Y } \quad \text { Regional income per capita i period } t
\end{aligned}
$$

Sub 1 = Subsector of Agriculture, Animal Husbandry, Hunting, and Agricultural Services area i period $t$

Sub 2 = Regional Forestry Subsector i period $\mathrm{t}$

Sub 3 = Regional Fisheries Subsector $\mathrm{i}$ period $\mathrm{t}$

From the estimation results of the OLS model above, it can be seen that if the independent variables (agriculture, livestock, hunting and service subsector, forestry subsector, and fisheries subsector) are constant then the value of Economic Growth is 6.055155 percent.

Agriculture, animal husbandry, hunting and service subsectors have a positive effect on GDP per capita with a coefficient value of 1.478361 and a significant value with a probability value of $0.0003<0.05$. This positive direction shows that the higher the value of the agriculture, animal husbandry, hunting and service subsectors, the higher the value of economic growth in North Sumatra Province. Other interpretations show that if the agriculture, livestock, hunting and services subsectors increase by one percent and it is assumed that the forestry and fisheries subsectors are constant then economic growth will increase by 1,478361 percent.

These results are consistent with the research hypothesis and in reality that the agriculture, livestock, hunting and service subsectors in reality have the greatest contribution to the North Sumatra GRDP. The results of the previous LQ analysis also showed that the 
average LQ value of the agriculture, livestock, hunting and service subsectors of 1.026> 1 indicates that this subsector is the superior or base subsector in North Sumatra.

The forestry subsector has a positive effect on GDP per capita with a coefficient value of 0.043550 with a probability value of $0.0300<0.05$. This positive direction shows that the more the value of the forestry subsector increases, the more the value of economic growth increases. If the value of the forestry sub-sector increases by one percent assuming the agriculture, livestock, hunting and services and fisheries sub-sectors are constant, the economic growth will grow by 0.043550 percent. The estimation results are in accordance with the research hypothesis.

Fisheries subsector has a positive effect on North Sumatra per capita GRDP with a coefficient value of 0.082362 and a significant value with a probability value of 0.0477 $<0.05$. This positive direction shows that the more the value of the fisheries subsector increases, the higher the value of North Sumatra's economic growth. If the value of the fisheries subsector increases by one percent assuming the agriculture, livestock, hunting and services subsector and the forestry subsector are constant, then economic growth will grow by 0.082362 percent. The estimation results are in accordance with the research hypothesis. However, if viewed from the LQ analysis shows a decrease in the value of LQ from 2014 to 2018. There are several things that are suspected to be the cause of the decline in the fisheries subsector to the North Sumatra GRDP, such as the structure of the fisheries business is still dominated by small scale businesses, still limited capture capacity lack of technological mastery causing almost every fisherman to still use traditional methods in catching fish, the lack of business capital sources and the still lack of response from the government especially the local government to socialize how the method of developing and structuring the fisheries sector. This of course should be one of the concerns for local governments to re-increase and develop regional potential sources and maintain the value of fishery excellence in North Sumatra.

The priority of economic development in the agricultural sector must be focused on the superior subsector. The magnitude of the effect of this sub-sector needs to be accompanied by efforts to increase economic activity in order to increase the added value of excess production in the agricultural sector, especially in the agricultural, livestock, hunting and service subsectors. The production of this derivative needs to be developed in the processing industry sector so that it is expected to absorb more labor and greater economic opportunities. The success of development in the agricultural sector will affect other sectors and can absorb labor and increase community income in an effort to reduce unemployment in North Sumatra.

Analysis of the determination of the base sector (superior) and determination of competitiveness is needed as a basis in development planning and allocating the right budget in North Sumatra so that the policies made by the regional government can be right on target to move the existing agricultural sectors and subsectors.

\subsection{Hypothesis Test Results}

Testing this hypothesis aims to determine whether the hypothesis that has been set is accepted or rejected statistically.

\section{a. T-Statistics Test}

To find out how much the value of the independent variable significantly or not partially tied to the variable, the T-Statistic Test was used. To test the effect of the independent variable on the dependent variable a hypothesis can be made:

$\mathrm{H} 0=$ partially has no significant effect on the dependent variable

$\mathrm{H} 1$ = partially significant effect on the dependent variable 
T-Statistic Test results show the probability value of subsector $1(0.0003<0.05)$, probability value of subsector $2(0.0300<0.05)$, and probability value of subsector $3(0.0477$ $<0.05)$. Based on the hypothesis determined, $\mathrm{H} 0$ is rejected and $\mathrm{H} 1$ is accepted with a $\mathrm{t}$-value $<0.05$, then the independent variables in this study are the agriculture, livestock, hunting and services subsector, forestry subsector, fisheries subsector, which significantly influence North Sumatra's GRDP.

\section{b. F-Statistics Test}

To find out how much the independent variable significantly or not influences the dependent variable together, the F-Statistic Test is used. To test this effect a hypothesis can be made:

$$
\begin{aligned}
& \mathrm{H} 0=\text { simultaneous no significant effect on the dependent variable } \\
& \mathrm{H} 1=\text { simultaneous significant effect on the dependent variable }
\end{aligned}
$$

The test results show from the results of data processing obtained F-Statistics value of 702,353 with a prob value. $0.0000<0.05$ so $\mathrm{H} 0$ is rejected and H1 is accepted. It can be concluded that the agriculture, livestock, hunting and services subsector, forestry subsector, and fisheries subsector have a significant effect of 702,353 on the GRDP in North Sumatra Province in the 2014-2018 period.

\section{c. Determination Coefficient Test Results (R2)}

The coefficient of determination R2 is used to show how much the influence of the independent variables together can provide an explanation of the dependent variable where the value of the coefficient of determination (R2) is between 0 to $1(0 \leq R 2 \leq 1)$. The smaller $\mathrm{R} 2$ near zero means the smaller the effect of the independent variable on the dependent variable. Conversely, if R2 gets closer to one, it shows the stronger influence of independent variables on the dependent variable.

Based on the results of panel data regression analysis obtained information that the coefficient of determination of 0.89 . This means that 89 percent of economic growth in the 25 districts of North Sumatra in 2014-2018 can be explained by the variables of the agriculture, livestock, hunting and services subsector, forestry subsector and fisheries subsector. While the remaining 11 percent is explained by other variables not examined in this study.

\section{Conclusion}

Based on the results of the analysis that has been carried out on the analysis of competitive commodities that are competitive between districts in North Sumatra, the following conclusions are obtained:

1. Based on the results of the LQ (Location Quetient) analysis, it shows that the agriculture, animal husbandry, hunting and service subsectors are the basic subsector (LQ> 1) in North Sumatra province including Mandailing Natal, South Tapanuli, North Tapanuli, Simalungung, Dairi, Karo, Deli Serdang, South Nias, Humbang Hasundutan, Pakpak Bharat, Serdang Bedagai, and Coal. The forestry sub-sector is one of the base or leading sectors in several districts, namely Mandailing Natal, South Tapanuli, Central Tapanuli, North Tapanuli, Toba Samosir, Dairi, Humbang Hasundutan, Pakpak Bharat, Samosir, Paluta, and North Nias. As for the fisheries sub-sector there are several districts as the base sector, namely Nias, Mandaling Natal, Central Tapanuli, Toba Samosir, Labuhanbatu, Asahan, Simalungun, Deli Serdang, South Nias, Samosir, Serdang Bedagai, and Coal.

2. Based on the panel data regression estimation results obtained that the agriculture, livestock, hunting and services subsector, forestry subsector and fisheries subsector have a positive and significant effect on the economic growth of the province of North Sumatra 
3. From the coefficient value on the estimation results, the economic growth variable can be explained by $89 \%$ by the variables of the agriculture, livestock, hunting and service subsector, forestry subsector, and fisheries subsector.

\section{References}

Arifin, B. (2001). Spektrum Kebijakan Pertanian Indonesia. Telaah Struktur,Kasus, Dan Alternatif Strategi. Erlangga. Jakarta.

Bahri, S. (2018). “Analisis Peran Sektor Pertanian Terhadap Perekonomian Kabupaten Sragen".

Badan Pusat Statistik (BPS). (2017). Sumatera Utara dalam Angka tahun 2017. Sumatera Utara.Enu, P. 2014. Analysis of the Agricultural Sector of Ghana and Its Economic Impact on Economic Growth. Journals Savap, 5 (4): 267-77.

Ghozali, I. (2013). Aplikasi Analisis Multivariat dengan Program IBM SPSS. Edisi 7. Semarang: Penerbit Universitas Diponogoro.

Haris, W.A. (2018). Analisis Peranan Subsektor Tanaman Pangan Terhadap Perekonomian Jawa Barat. Journal of Regional and Rural Development Planning, 1 (3): 231-42.

Hendayana, R. (2003). Aplikasi Metode Location Quotient (LQ) Dalam Penentuan Komoditas Unggulan Nasional. Jurnal Informatika Pertanian, 12.

Indramayu, K. and Indri M. (2018). Komoditas Unggulan Tanaman Pangan Untuk Mendukung Perekonomian Wilayah Kabupaten Indramayu. Jurnal Ruang P-, 4 (1): $57-65$.

Irwansyah, D.M. and Sonny. (2013). Analisis Pergeseran Struktur Ekonomi Dan Identifikasi Sektor Potensial Wilayah Pengembangan (Studi Kasus Di Kabupaten Bekasi, Provinsi Jawa Barat). Journal Social Economic of Agriculture, 2 (1): 7-28.

Oktavia, H.F. and Nuhfil H. (2016). Peran Sektor Pertanian Dalam Pembangunan Ekonomi Di Provinsi Jawa Timur ( Pendekatan Input-Output ). Jurnal Habitat, 27 (2): 72-84.

Pranoto, Y.S. and Haryono M. (2018). Kontribusi Sektor Pertanian Berdasarkan Keunggulan Wilayah Di Kabupaten Bangka. Caraka Tani: Journal of Sustainable Agriculture, (1): 42-49.

Prawoto, N. (2010). Pengembangan Potensi Unggulan Sektor Pertanian. Jurnal Ekonomi dan Studi Pembangunan, pp 1-19.

Syafa'at, N. (2000). Analisis Dampak Krisis Ekonomi Terhadap Kesempatan Kerja Dan Identifikasi Komoditas Andalan Sektor Pertanian Di Wilayah Sulawesi : Pendekatan Input-Output. Ekonomi dan Keuangan Indonesia, XLVIII (4): 369-93.

Sumatera Utara Dalam Angka (SUDA) Tahun 2015

Sumatera Utara Dalam Angka (SUDA) Tahun 2018

Todaro, M.P. and Stephen C.S. (2006). Pembangunan Ekonomi (Edisi Kesembilan, Jilid I). Jakarta : Erlangga

Wulandari, N.I. (2010). Penentuan Agribisnis Unggulan Komoditi Pertanian Berdasarkan Nilai Produksi Di Kabupaten Grobogan.nUniversitas Diponegoro.

Yulianita, A. (2009). Analisis Sektor Unggulan Dan Pengeluaran Pemerintah Di Kabupaten Ogan Komering Ilir. Journal of Economic \& Development, 7 (2):70-85.

Yusuf, M. (2012). Ekonomi Regional. Medan. UNIMED. 